Conclusion High levels of s ICAM 1 may be a a consequence of inflammation or tissue damage made by nitric oxide generated by xanthine oxidase.

\section{AB0029 SELECTIVE INHIBITION OF COX-2 ON ACID-INDUCED GASTRIC ULCERS: COMPARISON OF MELOXICAM, PIROXICAM AND NIMESULIDE}

H Schierok, I Erni, S Schlager, B Guth, M Pairet. General Pharmacology, Boehringer Ingelheim Pharma KG, Biberach, Germany

\subsection{6/annrheumdis-2001.934}

Background Non-steroidal anti-inflammatory drugs are known to have adverse effects on the gastro-intestinal system through the inhibition of prostaglandin synthesis by cyclooxygenase-1 (COX-1). Reducing inflammation by selectively inhibiting COX2 has reduced gastrointestinal side effects. The effect of selective COX-2 inhibition or non-selective inhibition on the aggravation of gastric lesions due to other causes, however, has not been thoroughly examined.

Objectives We tested the hypothesis that agents that selectively inhibit COX-2 (meloxicam and nimesulide) would aggravate HCL-induced gastric lesions in rats less than a nonselective inhibition (piroxicam).

Methods Gastric lesions were induced in male rats $(\mathrm{N}=10$ per group) using $0.45 \mathrm{~N} \mathrm{HCL}$. The test drug (1.5 or $3 \mathrm{mg} / \mathrm{kg}$ ) was administered s.c. $60 \mathrm{~min}$ before the instillation of HCL $(1 \mathrm{ml} /$ $100 \mathrm{~g} \mathrm{BW})$ into the stomach. One hour later the animals were euthanized and the stomachs were removed, rinsed, opened along the greater curvature and photographed. Lesions were quantified in the fundus region using computer-assisted planimetry of the digital images.

Results The stomach area of all groups was comparable. The results in terms of absolute ulcer area, ratio of ulcer area to total fundus area and this ratio as compared to the control group is summarised in the following Table 1.

\begin{tabular}{|c|c|c|c|c|c|c|}
\hline & $\begin{array}{l}\text { Meloxicam } \\
1.5 \mathrm{mg} / \mathrm{kg}\end{array}$ & $\begin{array}{l}\text { Meloxicam } \\
3 \mathrm{mg} / \mathrm{kg}\end{array}$ & $\begin{array}{l}\text { Nimesulide } \\
1.5 \mathrm{mg} / \mathrm{kg}\end{array}$ & $\begin{array}{l}\text { Nimesulide } \\
3 \mathrm{mg} / \mathrm{kg}\end{array}$ & $\begin{array}{l}\text { Piroxicam } \\
1.5 \mathrm{mg} / \\
\mathrm{kg}\end{array}$ & $\begin{array}{l}\text { Piroxicam } \\
3 \mathrm{mg} / \mathrm{kg}\end{array}$ \\
\hline $\begin{array}{l}\text { Ulcer } \\
\text { Area } \\
(\mathrm{mm} 2)\end{array}$ & $117 \pm 24$ & $105 \pm 16$ & $99 \pm 18$ & $137 \pm 21$ & $141 \pm 21$ & $\begin{array}{l}166 \pm \\
15^{*}\end{array}$ \\
\hline $\begin{array}{l}\text { Ratio } \\
\text { ulcer/ } \\
\text { fundus }\end{array}$ & $14.3 \pm 2.8$ & $12.6 \pm 1.6$ & $11.7 \pm 2.1$ & $16.5 \pm 2.6$ & $\begin{array}{l}17.4 \pm \\
2.9\end{array}$ & $\begin{array}{l}20.2 \pm \\
1.9^{*}\end{array}$ \\
\hline $\begin{array}{l}\% \\
\text { Control }\end{array}$ & 10.2 & -3.1 & -10.4 & 27.0 & 33.9 & $55.5^{*}$ \\
\hline
\end{tabular}

Conclusion This in vivo test supports the hypothesis that selective inhibition of COX-2 has less effect on acid-induced gastric ulcers in rats than a nonselective inhibition. In this test meloxicam had no effect on gastric lesions, nimesulide only a trend for ulcer enhancement but piroxicam produced a clear augmentation of HCL-induced gastric lesions.

\section{AB0030 BIOPSY FINDINGS IN ADULT-ONSET STILL DISEASE}

${ }^{1} \mathrm{CA}$ Montilla, ${ }^{2} \mathrm{E}$ Cuevas, ${ }^{2} \mathrm{~J}$ Abraham-Simón, ${ }^{1} \mathrm{CM}$ González, ${ }^{1} \mathrm{FJ}$ López-Longo, ${ }^{1}$ I Monteagudo, ${ }^{1} \mathrm{~L}$ Carreño, ${ }^{2} \mathrm{~J}$ Alcocer-Varela, ${ }^{2} \mathrm{D}$ Alarcón-Segovia. ${ }^{1}$ Rheumatology, Hospital General Universitario Gregorio Marañón, Madrid, Spain; ${ }^{2}$ Immunology and Rheumatology, Instituto Nacional de Nutrición Salvador de Zubirán, Mexico DF, Mexico

10.1136/annrheumdis-2001.935

Background The differential diagnosis of adult-onset Still disease involves cancer, infections and other rheumatic diseases. Thus, differential diagnosis frequently requires the performance of biopsies. However, there are not many reports about histological findings in these patients.

Objectives To describe biopsy findings in patients with adultonset Still disease.

Methods We have studied biopsies from 35 patients with adultonset Still disease performed between April of 1979 and December of 1999 in Salvador Zubirán Nutrition Institute.

Results $60 \%$ of all patients adult-onset Still disease underwent a biopsy. In lymphatic ganglions, which constitute the most frequent biopsy, the main finding is the loss of structure with lymphoid follicles of variable size and a sinusal part widened with arteries with hyalines and gross walls. In some samples, areas of necrosis and haemorrhage were found. In the liver appeared focal infiltrates of polymorphonuclear leukocytes in hepatic lobulille and lymphoplasmocitaries accumulates in porta spaces. In some patients an opening of sinusal and Disse spaces with focal necrosis area was described. In the spleen, polymorphonuclears were identified in red pulp, with a moderate amount of plasmatic cells and eosinophils, and an important widening of arterial walls. White pulp did not showed any disturbance. In the skin, it was demonstrated the presence of polymorphonuclears and lymphocytes infiltrates with a perivascular and perianexial predominance. Paraqueratosis areas were also described. Perivascular inflammatories infiltrates in the muscle with areas of necrosis were described. In the lung, a broadening of alveolar walls because of an inflammatory infiltrate composed by polymorphonuclears and lymphocytes was described. Areas of haemorrhage were also described.

Conclusion We have not found any characteristic histological finding of Still disease in the adult. In most of the biopsies predominate non-specific inflammatories infiltrates.

\section{AB0031 PROTEIN SULFHYDRYLS AND CARBONYL CONTENT CHANGES IN SERA OF RHEUMATOID ARTHRITIS PATIENTS}

${ }^{1} \mathrm{M}$ Serteser, ${ }^{2} \mathrm{D}$ Evcik, ${ }^{1} \mathrm{~T}$ Köken. ${ }^{1}$ Biochemistry; ${ }^{2}$ Physical Medicine and Rehabilitation, Kocatepe University, Afyon, Turkey

10.1136/annrheumdis-2001.936

Objectives Oxygen free radicals play a major role in the generation of acute and chronic inflammatory processes one of which is Rheumatoid Arthritis (RA). Biological thiols or sulfhydryls protect cells against oxidative stress. Introduction of carbonyls into proteins is the consequences of the protein oxydation. This study is planned to investigate the roles of oxygen free radicals in rheumatoid arthritis.

Methods In this study; according to ACR criteria, a total of 29 RA patients $(\mathrm{M} / \mathrm{F}=7 / 22)$ aged between 31 to 68 years old are included. They were physically evaluated by the number of tender points. Rutin labaratory investigations (ESR, CRP, RF, biochemically parameters) were also evaluated. Control group were 
selected from healthy adults with same age. Than blood samples were investigated in biochemistry unit. Protein carbonyl content of the samples were determined according to the method described by Levine et al and the modified method was described by Koster et al. These two methods were used for determination of protein sulphydyrls.

Results The sulfhydryl contents of RA patients were found significantly decreased than those in age and sex matched controls, $396,26 \pm 42,33 \mathrm{mmol} / \mathrm{L}$ and $677,21 \pm 59,98 \mathrm{mmol} / \mathrm{L}$ respectivelly $(\mathrm{p}<0,001)$. On the other hand the carbonyl contents of RA patients were found significantly increased than those in controls, $105,45 \pm 14,26 \mathrm{mmol} / \mathrm{L}$ and $93,65 \pm 10,49 \mathrm{mmol} / \mathrm{L}$ respectively $(\mathrm{p}<0,05)$.

Conclusion These changes in oxidative stress markers could indicate the role of free radical attacks on proteins.

\section{REFERENCES}

1 Levine RL, Garland D, Oliver CN, Amici A, et al. Determination of carbonyl content in oxidatively modified proteins. Methods Enzymol. 1990;186:464-78

2 Koster JF, Biemond P, Swaak JG. Intracellular and extracellular sulfhydryl levels in rheumatoid arthritis. Ann Rheum Dis. 1986:45:44-6

\section{AB0032 BONE DESTRUCTION IN RHEUMATOID SYNOVIA}

${ }^{1} \mathrm{~K}$ Taniguchi, ${ }^{1} \mathrm{Y}$ Kuga, ${ }^{1} \mathrm{~K}$ Ito, ${ }^{1} \mathrm{~S}$ Uchida, ${ }^{2} \mathrm{~T}$ Uchida, ${ }^{3} \mathrm{H}$ Oda. ${ }^{1}$ Rheumatic and Collagen Diseases, Tokyo Government General Hospital of Bokutoh, Tokyo, Japan; ${ }^{2}$ Department of Oral Anatomy, Hiroshima University, Hiroshima, Japan; ${ }^{3}$ Department of Orthopaedic Surgery, University of Tokyo, Tokyo, Japan

10.1136/annrheumdis-2001.937

Background Rheumatoid Arthritis (RA) is characterised by severe and irreversible bone destruction in affected joints on its last stage. On the other hand, bone absorption by osteoclasts may be a natural physiological phenomenon as bone remodelling in mature manhood. Throughout our life, bone is constantly renewed with the process of old bone removing and new bone supplement. Osteoclasts are derived from the hematopoietic granulocyte/macrophage colony forming units, which also become to monocytes and macrophages, and their progenitors move from bone marrow to bone surface through the circulation or direct migration, and differentiate to functional mature osteoclasts with stimulation of some cytokines and/or direct contact. In RA, or another bone destructive disease, activated osteoclasts certainly have a critical role in bone destruction. But, is that all? How bone is broke down in RA? We have speculation that some cells derived from rheumatoid synovia were activated by inflammatory cytokines abundant in the joint of RA and take a significant role in the destruction of the bone.

Objectives To elucidate what mechanism is there, we have observed the pannus-bone junctions in detail.

Methods The specimens of the destructive bone derived from the RA patients under arthroplasty with their consent. Tissue sections from the pannus-bone junctions at sites of bone erosion were examined by hematoxylin-eosin staining, tartrate-resistant acid phosphatase (TRAP) staining, and electron microscopy. Synovial tissues were also examined immunohistochemically.

Results The specimens of the destructive bone derived from the RA patients showed that there were many not-classical osteoclasts in the area of bone erosions. Cells in the erosive front of $\mathrm{RA}$ are divided in four groups, the authentic osteoclasts, mononuclear osteoclasts, fibroblast-like cells and monocytes. The electron microscopy observations revealed that the fibroblast-like cells certainly have some contact with bone matrix. TRAP- positive cells and vitronectin receptor -positive cells were seen in frozen sections of synovial membrane from the patient with RA. Conclusion Our result showed that not only authentic osteoclasts, but the mononuclear cells and fibroblast-like cells were activated and have some role in bone destruction of RA.

\section{REFERENCES}

1 Arthritis Rheum. 1984;27:968-75

2 Ann Rhuem Dis. 1993;52:133-7

\section{AB0033 ASSOCIATION OF C ? REACTIVE PROTEIN WITH BONE MINERAL DENSITY AND BIOCHEMICAL MARKERS OF BONE TURNOVER IN OSTEOPOROSIS PATIENTS WITH RHEUMATOID ARTHRITIS}

DA Gukasyan, EL Nasonov, RM Balabanova, AV Smirnov. Department of Rheumatology, Institute of Rheumatology of RAMS, Moscow, Russia

10.1136/annrheumdis-2001.938

\section{Background}

Objectives To examine the association of $\mathrm{C}$ ? reactive protein (CRP) on bone mineral density and biochemical markers of bone turnover in osteoporosis patients with rheumatoid arthritis (RA). Methods Out of the 60 female patients with proved diagnosis of RA aged 34-64 years.; Gr. 1: 30 women with preserved menstrual cycle (median age 41,5 years, disease duration 9,5 years, rheumatoid factor positive $80 \%$ ). Gr. 2: 30 women with postmenopause. (median age 56,2 years, disease duration 10,2 years, rheumatoid factor positive $83,3 \%$ ). Both groups have not undergone any glucocorticoid or antiosteporodic therapy. Bone mineral density (BMD) was measured with a ?QDR Hologic 1000 plus? by Dual Energy X -Ray Absorptiometry (DEXA) method, for the lumbar spine and in proximal segments of the femur. Concentration of CRP, bone alkaline phosphatase (BAP) and deoxypyridinoline (Dpir) was studded by immunoensymatic method.

Results In gr.1 of RA patients by with increase of concentration $(\mathrm{CRP})>50 \mathrm{mg} / \mathrm{l}$ reliable decrease of BMD was determined in all studied sections of proximal segment of the femur, as compared with patients with CRB $£ 50 \mathrm{mg} / \mathrm{l}$ level, and in gr. 2 similar change was observed only in BMD L1-L4. Negative correlation between CRB and BMD femoral neck $(r=-0,53$, $<0,005)$ in RA patients of gr. 2, and in gr.1 with CRB and BMD of femoral neck $(r=-0.5, \partial<0,01)$ was revealed. Direct significant correlation between the level of Dpir and CRP has be revealed in both groups $(r=0,46, \partial=0,04$ and $r=0,51, \partial=$ 0,02 relatively). Reliable correlation between BMD L1-L4 and CRP, also between BAP and CRP was not revealed.

Conclusion Increase of CRB concentration in RA correlated with growing of bone resorption markers and decrease of BMD of femoral neck.

\section{AB0034 THE DISTRIBUTION OF HLA-DRB1 ALLELES IN THE RUSSIAN POPULATION WITH PROTRACTED RHEUMATOID ARTHRITIS (RA)}

LA Taukumova, IA Gousseva. Department of Clinical Pharmacology, Institute of Rheumatology of RAMS, Moscow, Russia

10.1136/annrheumdis-2001.939

Background 